\title{
IAMJ
}

INTERNATIONAL

AYURVEDIC

MEDICAL JOURNAL

ISSN: 2320-5091

Impact Factor: 6.719

\section{AYURVEDIC CLINICAL APPROACH FOR THE MANAGEMENT OF AMAVATA (RHEUMATOID ARTHRITIS)}

\author{
Saroj Kumar Debnath ${ }^{1 *}$, Laxmidhar Barik ${ }^{2}$, Dipsundar Sahu ${ }^{3}$, Debajyoti Das ${ }^{4}$ \\ 1, 2, 3, 4. Research Officer (Ayurveda), Central Ayurveda Research Institute, Kolkata, West Bengal, India, \\ Central Council for Research in Ayurvedic Sciences, Ministry of AYUSH, Government of India
}

Corresponding Author: sarojkumardebnath@gmail.com

https://doi.org/10.46607/iamj2209082021

(Published Online: August 2021)

Open Access

(C) International Ayurvedic Medical Journal, India 2021

Article Received: 05/07//2021 - Peer Reviewed: 14/07/2021 - Accepted for Publication: 22/07/2021

Check for updates

\section{ABSTRACT}

In Ayurveda, Acharya Madhava Kar mentioned first the Amavata as a special disease entity. According to the clinical features and pathogenesis Amavata very closely resembles Rheumatoid arthritis. In Amavata, Ama (biotoxin) and Vata (biophysical force or kinetics) are playing the most important role in the samprapti (pathogenesis) of this disease. The Chikitsa (management) of Amavata (Rheumatoid arthritis) is more clearly and precisely described in Chakradutta. Acharya Chakradatta was the pioneer in describing the principles of treatment for this disease, which are Langhana (body lightness procedure), Swedana (warm compress), drugs having Tikta-Katu Rasa (bitter-pungent taste) and Deepana (gastric stimulant) action, Virechana (purgation therapy), Snehapana (intake of grita or oil) and Anuvasana (enema with Ayurvedic oil) as well as Ksharabasti (enema with Ayurvedic alkali preparation).

Keywords: Amavata, Rheumatoid arthritis, Chikitsa, management, Chakradutta

\section{INTRODUCTION}

Rheumatoid arthritis is a chronic, progressive autoimmune arthropathy and characterized by bilateral symmetrical involvement of joints with some systemic clinical manifestations ${ }^{1}$. According to the clinical features and pathogenesis Amavata very closely re- sembles Rheumatoid arthritis. In Ayurveda, Acharya Madhava kar mentioned first the Amavata as a special disease entity. In Amavata, Ama (biotoxin) and Vata (biophysical force or kinetics) are playing the most important role in the samprapti (pathogenesis) 
of this disease. ${ }^{2}$ The entity Amavata (Rheumatoid arthritis) and its Nidana (aetiology) as well as Chikitsa (management) both are available since the period of Charaka in a different context. The Chikitsa (management) of Amavata (Rheumatoid arthritis) is more clearly and precisely described in Acharya Chakradutta. ${ }^{3}$ In modern medicine aetiology and management of Rheumatoid arthritis remains obscure. So many adverse effects are seen to date of the modern medicines which are used for the management of Rheumatoid arthritis.

Ama: The improper digestive mechanism in the G.I.T. and improper metabolism in the cell, as well as tissue, is called Mandagni (poor digestive capacity) and it is mainly responsible for the genesis of Ama. In general, the term Ama means unripe or partially digested food that is unwholesome to the body ${ }^{4}$. Thus, it is a product due to improper digestion and or metabolism and it is mainly related to the state of Agni (digestion or metabolism capacity). So, it is an important factor for the pathogenesis of Amavata (Rheumatoid arthritis) and most of the diseases.

The etymology of Ama: In Amarkosha (Sanskrit thesaurus) the word Ama is derived as a Combination of 'Am' Dhatu with 'Nich' Pratyaya forms the word Ama that means the substance subjected to digestion and it is harmful to the different of Srotasa (channel) is known as Ama ${ }^{5}$. In Vachaspatyam (Sanskrit dictionary) the word Ama is derived from the ' $A m$ ' Dhatu with the suffix 'A'. It means improper or partially digested matter that damages the different srotasa or channels of the body ${ }^{6}$.

Vata or Vayu: Vata or Vayu is the important force for dynamic or kinetic or motion or movement of a living body. In its normal condition living body performs proper movements and activities. If Vayu is vitiated due to Ahit (unwholesome) ahara (diet) and vihara (lifestyle) the movements and activities of the living body will be rearranged. All the life activities of the living body especially voluntary and involuntary movements are performed under the control of Vata dosha. It is the most important pathogenic factor of Amavata. patients of Amavata become crippled gradually due to vitiation of Vata with Ama and functions of Vata are disturbed in Amavata. $^{7}$

The etymology of Vata or Vayu: The term 'Vata' is derived from the root 'Va Gatigandhanayoh' which means to move, to dynamic, to enthuse, to make known and become of (Amarkosha, Shabdastoma Mahanidhi $)^{8}$. "Vati Iti Vayu" substance which has got movement or motion, is known as Vayu (Vachaspatyam, Shabdakalpadruma) ${ }^{9}$. In classics, it is also referred to by synonyms like Anila, Marut, Pavana etc.

Nidana (Etiology) of Amavata: According to Acharya Charaka, a single etiological factor may produce a single disease, or many factors together may produce a single disease and vice-versa. ${ }^{10}$ In the context of disease Amavata (Rheumatoid arthritis) is mostly a disease having a multifactorial aetiology. Acharya Madhava has given specific etiological factors responsible for the causation of the disease Amavata and these are Viruddhahara (Unwholesome Diet), Viruddhacheshta (Erroneous Habits), Mandagni (Diminished Agni), Nishchalata (Sedentary Life), Exertion immediately after taking Snigdha Ahara (Oily food). ${ }^{11}$ According to modern medicine Rheumatoid arthritis is a disease having multi-factorial aetiology. Although the cause of Rheumatoid arthritis remains obscure. Some of the concepts regarding aetiology are Autoimmunity, Genetic susceptibility, Super Antigen Driven Diseases, Molecular Mimicry, Infections, Endocrinal factors, Psychological Factors etc.

\section{Rupa/Lakshana (Clinical features) of Amavata} (Rheumatoid arthritis):

Madhavakara, Bhavamishra, and others have described the Rupa/Lakshana (Clinical features) of Amavata (Rheumatoid arthritis) clearly. It can be classified under the following headings:

1. Pratyatma Lakshana (Cardinal Clinical Features): Sandhi Shula (Joint-pain), Sandhi Shotha (Joint-swelling), Sandhi Stabdhata (Stiffness of joint), Sandhi Sparshasahyata (Tenderness over joint). ${ }^{12}$

2. Samanya Lakshana (General Clinical Features): Angamarda (body ache or malaise), Aruchi 
(anorexia), Trishna (thirst), Alasya (laziness/lethargy), Gaurava (heaviness of body), Jwara (fever), Apaka (indigestion), Angashunata (Oedema of deferent parts of the body including joints). ${ }^{13}$

3. Doshanubandha Lakshana (Clinical features according to Dosha predominance): Vatanubandha - Ruka (pain). Pittanubandha - Daha (burning sensation), Raga (redness of affected joints). Kaphanubandha - Stimita (lack of mobility), Guruta (heaviness), Kandu (itching). Vata Pittanubandha - Ruka (pain), Daha (burning sensation), Raga (redness of affected joints). Vata Kaphanubandha - Ruka (pain), Stimita (lack of mobility), Guruta (heaviness), Kandu (itching). Kapha Pittanubandha - Stimita (lack of mobility), Guruta (heaviness), Kandu (itching), Daha (burning sensation), Raga (redness of affected joints). Sannipataja - Symptoms for all three doshas. ${ }^{14}$

4. Pravriddhavastha Lakshana (Clinical features in aggravated condition): Agnidaurbalya (lack of digestive capacity), Praseka (excessive salivation), Aruchi (anorexia), Gaurava (heaviness of body), Vairasya (improper taste sensation), Ruja and shotha in Hasta, Pada, Shiro, Gulpha, Trika, Janu, Uru Sandhi (pain and swelling in hands, legs, head, ankle, low back, knee, hip joints), Vrishchika damshavata vedana (scorpion bite like pain), Utsahahani (lack of enthusiasm), Kukshikathinya (tightness in the abdomen), Kukshishula (pain in the abdomen), Vibandha or Vidvibaddhata (constipation), Antrakujana (borborygmi), Anaha (bowel and urine not clear), Chhardi (vomiting), Hridgraha (pain in the precordial region), Jadyata (less physical activity or stiffness of the body or immobility), Bhrama (Vertigo), Murchcha (lack of sensory \& motor functions), Nidra-viparyaya (disturbed sleep), Daha (burning sensation), Bahumutrata (polyuria). ${ }^{15}$

According to Modern Medicine Criteria to Diagnose Rheumatoid Arthritis ${ }^{16}$ :

As per American Rheumatism Association (1988) the following criteria has been laid down: 1) Morning stiffness, 2) Arthritis of three or more joints areas, 3) Arthritis of hand joints, 4) Symmetrical arthritis, 5) Rheumatoid nodules, 6) Rheumatoid factors, 7) Radiological changes. a) Here first four criteria should be present for 6 weeks or more. b) Diagnosis of Rheumatoid Arthritis is made with four or more criteria.

\section{According to Modern Medicine Management for} Rheumatoid Arthritis ${ }^{17}$ :

a) General Principales:

The goals of therapy of Rheumatoid Arthritis are 1) relief of pain, 2) reduction of inflammation, 3) Protection of articular structures, 4) maintenance of function and 5) control of systemic involvement.

b) General Line of treatment:

1) Nonsteroidal Anti-Inflammatory Drugs,

2) Disease -Modifying Anti Rheumatic Drugs,

3) Glucocorticoid Therapy,

4) Immunosuppressive Therapy,

5) Surgery.

Chikitsa (Management) of Amavata (Rheumatoid Arthritis):

Acharya Chakradatta was the pioneer in describing the principles of treatment for this disease, which are Langhana (lightness the body), Swedana (warm compress), drugs having Tikta-Katu Rasa (bitterpungent taste) and Deepana (gastric stimulant) action, Virechana (purgation), Snehapana (intake of grita or oil) and Anuvasana (enema with Ayurvedic oil) as well as Ksharabasti (enema with Ayurvedic alkali preparation). ${ }^{18}$ Bhava Mishra and Yogratnakara have added Upanaha (locally applied Ayurvedic medicinal paste) without Sneha (oil) to these therapeutic measures. Which are as follows:

i) Langhana: Langhana is an Ayurvedic measure which gives lightness to the body. It is the first line of management for the treatment of Amavata (Rheumatoid Arthritis).

ii) Swedana: Ruksha Sweda (dry warm compress) is administered in the management of Amavata in the form of Baluka Pottali (warm compression with sand).

iii) Katu Tikta Deepana Dravyas: Katu (pungent) tikta (bitter) deepana (gastric stimulant) dravyas (substances) are indicated in Amavata (Rheumatoid 
Arthritis) because of their Deepana and Pachana (digestive) actions.

iv) Virechana: After administering Langhana, Swedana and Tikta, Katu, Deepana dravyas, doshas attain niramavastha (without $a m a$ ) and it may require elimination from the body by Shodhana karma (purification therapy) and for that purpose Virechana karma (purgation therapy) should be advised to the patient.

v) Snehapana: Shamana Snehapana (intake of grita e.t.c. in reduced dose) should be given to the patient to pacify the rukshata (dryness) after administering the above-mentioned therapies.

vi) Basti: It is one kind of enema therapy. It is mainly three types, and these are Anuvasana, Asthapana or Niruha Basti and Uttar Basti. The first two are administered through anas and the last one is administered through the urethra or vagina. In Anuvasana Basti Ayurvedic medicated oil is used, in Asthapan Basti Ayurvedic kasaya (decoction) is mainly used.

\section{DISCUSSION}

It is the first line of measure for the management of Amavata (Rheumatoid arthritis) which is considered as Amashayottha Vyadhi (disease generated due to vitiation of the stomach) and also Rasaja Vikara (vitiation of rasa dhatu). Charaka has also advised Langhana (body lightness procedure) in Samavata (vata is vitiated with ama). ${ }^{19}$ In Yogratnakara, Langhana (body lightness procedure) has been mentioned as the best measure for the treatment of Ama (biotoxin). It has been described that Sama dosha (dosha is vitiated with ama) cannot be eliminated from the body until and unless Ama (biotoxin) attains the Pakva (ripe/mature state) state and for this purpose Langhana (body lightness procedure) is the best therapy. ${ }^{20}$ Langhana (body lightness procedure) is contraindicated in vata vriddhi (increased vata dosha), but it is indicated in samavata (Vata is vitiated with ama) condition. Hence it is necessary to stop Langhana as soon as Nirama Vata (vata dosha without ama) state is achieved. In the management of Amavata, Ruksha Sweda (dry warm compression) has been applied in the form of Baluka Pottali (warm compression with sand), due to the presence of Ama (biotoxin). Snigdha Sweda (moist warm compression) can be administered in the chronic stage of the disease when Rukshata (dryness) is increased in the dhatus (tissues). Swedana (warm compression) has been specially indicated in the presence of Stambha (stiffness of the body), Gaurava (heaviness of the body) and Shoola (pain) and these are predominant features of Amavata. ${ }^{21}$ Ushna Jalapana (drinking of lukewarm water), a kind of internal Swedana is also indicated in Amavata and it has Deepana (gastric stimulant), Pachana (digestive), Jwaraghna (antipyretic), and Srotoshodhaka (channel cleansing) action. ${ }^{22}$ Swedana (warm compress) also helps to liquefy the doshas and aids in their transportation from Shakha (periphery of the body) to Koshtha (intestine) so that the doshas can be eliminated easily by shodhana (purification) therapy. Katu Tikta Rasa dravyas (pungent bitter tasted substances) are supposed to increase Vata dosha (bio force) and these are indicated in Amavata because of their Deepana (gastric stimulant) and Pachana (digestive) actions. These drugs increase Agni (digestive capacity) due to their Laghu-Tikshna guna (light-sharp property) and help to digest Ama (unwholesome metabolites), remove excessive Kledaka kapha (one type of Kapha) and prevent further production of Ama (biotoxin). Salivary and gastric secretions are increased by the use of Katu rasa (pungent taste). Apart from this, they improve intestinal motility by the action of the Vatanulomaka (subside Vata Dosha) property. After giving the following therapy Langhana (body lightness procedure), Swedana (warm compress) and Tikta (bitter), Katu (pungent), Deepana (gastric stimulant) dravyas (substances), doshas (Vata, Pitta \& Kapha) come into niramavastha (without ama) and it is required to eliminate from the body by Shodhana karma (purification therapy). Generally, Vamana karma (vomiting therapy) precedes Virechana karma (purgation therapy) but in Amavata (Rheumatoid arthritis), the patients should be advised for Virechana karma (purgation therapy) because the production of Ama is the result of Avarana (covering effect) of Pittasthana (site of pitta) by Kledaka Kapha (one type 
of Kapha), thus hampering the digestive capacity of the Pachaka Pitta (digestive enzymes). Virechana (purgation) helps to remove the Avarana (covering effect) produced by Kledaka Kapha (one type of kapha) and it is also the most suited therapy for the sthanika Pitta dosha (localized pitta dosha).Clinical manifestations of Amavata (Rheumatoid arthritis) like Anaha (bowel and urine not clear), Vibandha (constipation), Antrakujana (borborygmi), Kukshishula (pain in the abdomen), etc. are indicative of Pratiloma Gati of Vata (opposite motion of vata) and these are best controlled by Virechana (purgation), while Vamana (vomiting) is likely to aggravate these manifestations. The patient should be subjected to Shamana Snehapana (intake of grita e.t.c. in reduced dose) after giving the above-mentioned therapies which are justified based on the following reasons. The above therapeutic measures employed are likely to produce so far Rukshata (dryness) in Dhatus (tissues) and it may aggravate the vata dosha (bio force) and provoke further the disease process and it is best prevented by Shamana Snehapana (intake of grita e.t.c. in reduced dose). The Bala (strength) of the patient is decreased due to Shodhana (purification) therapy and the nature of the disease process. It is effectively controlled by the administration of Snehapan (intake of Grita, Taila e.t.c.) as it is the Balavardhaka (strength enhancer) regimen and Shamana Snehapana (intake of Grita e.t.c. in reduced dose) is also augmented the Agni (digestive capacity). ${ }^{23}$ Snehapana (intake of Grita, Taila e.t.c.) is also prescribed in the case of Asthimajjagata Vata (bone and bone marrow affection by vitiated Vata Dosha) and in Amavata (Rheumatoid arthritis) Asthi (bone) and majja (bone marrow) dhatus (tissue) are also affected. ${ }^{24}$ Snehapana (intake of Grita, Taila e.t.c.) pacifies the aggravated Vata dosha (bio force) due to its Vatanulomana (Vata Dosha pacifier) effect and it is indicated in Amavata (Rheumatoid arthritis) when there is a predominance of Vata Dosha in its Nirama (without Ama) stage. In Amavata (Rheumatoid arthritis), Samana (pacifier) Snehapan (intake of grita or oil) is administered with Deepana (gastric stimulant) and Pachana (digestive) Dravyas (substances) as
Amavata (Rheumatoid arthritis) patients are prone to develop derangement of digestion. Vata (bio force) is the most important pathological factor in the pathogenesis of Amavata (Rheumatoid arthritis) among three doshas (Vata, Pitta \& Kapha). Basti (enema therapy) is the best treatment for the management of Vata (Bioforce). In Amavata (Rheumatoid arthritis) another important causative factor is Ama (biotoxin). Basti (enema therapy) also increases Agni (digestive capacity) and it will help to eliminate the causative factors for the disease process. In Amavata (Rheumatoid arthritis), both Anuvasana (enema with Ayurvedic oil), as well as Asthapana or Niruha Basti (enema with Ayurvedic decoction), have been administered. Anuvasna basti (enema with Ayurvedic oil) reduces dryness of the body caused by the Amahara (elimination of bio-toxin) treatment, alleviates Vata dosha (bio force), maintains the proper function of Agni (digestive capacity) and nourishes the body. Asthapana or Niruha Basti (enema with Ayurvedic decoction) eliminates doshas (unwholesome materials into the body) which are brought into the koshtha (large intestine) by langhana (body lightness procedure) and other therapies. In addition to the generalized effects, Basti (enema therapy) also helps for local beneficial effects by eliminating Anaha (bowel and urine not clear), Antrakujan (borborygmi), Vibandha (constipation), etc. Saindhavadi Taila (Ayurvedic medicated oil) has been mentioned for Anuvasana and Kshara (alkali in nature) Basti (enema therapy) for Asthapana (enema with Ayurvedic decoction). ${ }^{25}$

\section{CONCLUSION}

Based on samprapti (pathogenesis) and lakshan/rupa (clinical manifestations) Amavata is more similar to Rheumatoid arthritis. Ama (biotoxin) and Vata (biophysical force or kinetics) both are the most important pathological factors for samprapti (pathogenesis) and lakshan/rupa (clinical features) of Amavata (Rheumatoid arthritis). Samprapti bighatan (break down of pathogenesis) is the treatment principle in Ayurveda. Acharya Chakradatta first described the Ayurvedic principles of treatment for Amavata (Rheumatoid arthritis), which are Langhana (body 
lightness procedure), Swedana (warm compress), Katu Tikta Deepana Dravyas (pungent, bitter tasted gastric stimulant substances), Virechana (purgation therapy), Snehapana (intake of Grita etc.), Anuvasana (enema by Ayurvedic medicated oil) and Ksharabasti (enema by Ayurvedic alkali preparation).

\section{REFERENCES}

1. Harrison TR, Anthony S. Fauci et al. Harrison's Principles of Internal Medicine, Ed 14, Vol.2, McGraw Hill, New York, 1998. pp. 1880-87.

2. Madhavakara, Rakshita V, Dutta S, Shastri S, Upadhyaya Y. MadhavaNidana (MadhukokoshaVyakya with Vidyotini Hindi Commentary), Ed 26, Part. I, Chaukhambha Sanskrit Sanathana, Varanasi, 1996, pp. 46064.

3. Chakrapabni Datta, Sengupta D, Sengupta U, Senserma K, Bhattacharyya S. Chakradutta, Amavata chikitsa, Ed 1, Deepayan, Kolkata, 2000, pp. 138-141.

4. Madhavakara, Rakshita V, Dutta S, Shastri S, Upadhyaya Y. MadhavaNidana (MadhukokoshaVyakya with Vidyotini Hindi Commentary), Ed 26, Part. I, Chaukhambha Sanskrit Sanathana, Varanasi, 1996, pp. 46064.

5. Amarasimha, Shastri H. Amarakosha with Maniprabha Hindi Commentary, Ed 6, Chowkhamba Sanskrit Series Office, Varanasi, 1998, pp. 55-67.

6. Bhattacharya T. Vachaspatyam: a comprehensive Sanskrit dictionary, Chowkhamba Sanskrit Series Office, Varanasi, pp. 46-54.

7. Agnivesha, Charaka, Dridhbala, Sharma R K, Dash B. Charaka Samhita (Chakrapani Datta's Ayurveda Dipika), Sutrasthan, Ed 1, Reprint, Chowkhamba Sanskrit Series Office, Varanasi, 2012, pp. 156-68.

8. Amarasimha, Shastri H. Amarakosha with Maniprabha Hindi Commentary, Ed 6, Chowkhamba Sanskrit Series Office, Varanasi, 1998, pp. 55-67.

9. Bhattacharya T. Vachaspatyam: a comprehensive Sanskrit dictionary, Chowkhamba Sanskrit Series Office, Varanasi, pp. 46-54.

10. Agnivesha, Charaka, Dridhbala, Sharma R K, Dash B. Charaka Samhita (Chakrapani Datta's Ayurveda Dipika), Vimansthan, Ed 1, Reprint, Chowkhamba Sanskrit Series Office, Varanasi, 2012, pp. 179-80.

11. Madhavakara, Rakshita V, Dutta S, Shastri S, Upadhyaya Y. MadhavaNidana (MadhukokoshaVyakya with Vidyotini Hindi Commentary), Ed 26, Part. I, Chau- khambha Sanskrit Sanathana, Varanasi, 1996, pp. 46064.

12. Madhavakara, Rakshita V, Dutta S, Shastri S, Upadhyaya Y. MadhavaNidana (MadhukokoshaVyakya with Vidyotini Hindi Commentary), Ed 26, Part. I, Chaukhambha Sanskrit Sanathana, Varanasi, 1996, pp. 46064.

13. Madhavakara, Rakshita V, Dutta S, Shastri S, Upadhyaya Y. MadhavaNidana (MadhukokoshaVyakya with Vidyotini Hindi Commentary), Ed 26, Part. I, Chaukhambha Sanskrit Sanathana, Varanasi, 1996, pp. 46064.

14. Madhavakara, Rakshita V, Dutta S, Shastri S, Upadhyaya Y. MadhavaNidana (MadhukokoshaVyakya with Vidyotini Hindi Commentary), Ed 26, Part. I, Chaukhambha Sanskrit Sanathana, Varanasi, 1996, pp. 46064.

15. Madhavakara, Rakshita V, Dutta S, Shastri S, Upadhyaya Y. MadhavaNidana (MadhukokoshaVyakya with Vidyotini Hindi Commentary), Ed 26, Part. I, Chaukhambha Sanskrit Sanathana, Varanasi, 1996, pp. 46064.

16. Harrison TR, Anthony S. Fauci et al. Harrison's Principles of Internal Medicine, Ed 14, Vol.2, McGraw Hill, New York, 1998. pp. 1880-87.

17. Harrison TR, Anthony S. Fauci et al. Harrison's Principles of Internal Medicine, Ed 14, Vol.2, McGraw Hill, New York, 1998. pp. 1880-87.

18. Chakrapabni Datta, Sengupta D, Sengupta U, Senserma K, Bhattacharyya S. Chakradutta, Amavata chikitsa, Ed 1, Deepayan, Kolkata, 2000, pp. 138-141.

19. Agnivesha, Charaka, Dridhbala, Sharma R K, Dash B. Charaka Samhita (Chakrapani Datta's Ayurveda Dipika), Sutrasthan, Ed 1, Reprint, Chowkhamba Sanskrit Series Office, Varanasi, 2012, pp. 156-68.

20. Maharsi Vagbhat, Sen U, Sen D, Sensharma K, Bhattacharyya S, Hastang Hridaya, Ed 1, Deepayan, Kolkata, 1999, pp. 231-32.

21. 21. Agnivesha, Charaka, Dridhbala, Sharma R K, Dash B. Charaka Samhita (Chakrapani Datta's Ayurveda Dipika), Sutrasthan, Ed 1, Reprint, Chowkhamba Sanskrit Series Office, Varanasi, 2012, pp. 156-68.

22. Agnivesha, Charaka, Dridhbala, Sharma R K, Dash B. Charaka Samhita (Chakrapani Datta's Ayurveda Dipika), Chikitsasthan, Ed 1, Reprint, Chowkhamba Sanskrit Series Office, Varanasi, 2012, pp. 190-94.

23. Agnivesha, Charaka, Dridhbala, Sharma R K, Dash B. Charaka Samhita (Chakrapani Datta's Ayurveda Dipi- 
ka), Chikitsasthan, Ed 1, Reprint, Chowkhamba Sanskrit Series Office, Varanasi, 2012, pp. 190-94.

24. Agnivesha, Charaka, Dridhbala, Sharma R K, Dash B. Charaka Samhita (Chakrapani Datta's Ayurveda Dipika), Chikitsasthan, Ed 1, Reprint, Chowkhamba Sanskrit Series Office, Varanasi, 2012, pp. 190-94.

25. Chakrapabni Datta, Sengupta D, Sengupta U, Senserma K, Bhattacharyya S. Chakradutta, Amavata chikitsa, Ed 1, Deepayan, Kolkata, 2000, pp. 138-141.

\section{Source of Support: Nil Conflict of Interest: None Declared}

How to cite this URL: Saroj Kumar Debnath et al: Ayurvedic Clinical Approach For The Management Of Amavata (Rheumatoid Arthritis). International Ayurvedic Medical Journal \{online\} 2021 \{cited August 2021\} Available from: http://www.iamj.in/posts/images/upload/1737_1743.pdf 